\title{
Deskripsi Keterampilan Komunikasi dan Kolaborasi Siswa SMA pada Pembelajaran Titrasi Asam-Basa dengan Model Inkuiri Terbimbing dan Berbasis Masalah
}

\section{Description of Communication and Collaboration Skills of High School Students in Acid-Basic Titration Learning with Guided Inquiry and Problem-Based Model}

\author{
N Rizal ${ }^{1}$ and Z Fitriza ${ }^{1 "}$ \\ 1 Pendidikan Kimia, Universitas Negeri Padang, \\ Jl. Prof. Dr. Hamka, Air Tawar Barat, Padang Utara, Sumatera Barat, Indonesia. 25171 \\ *zonaliafitriza@gmail.com
}

\section{ARTICLE INFO}

Received on:

21 August 2020

Revised till:

28 November 2020

Accepted on:

28 November 2020

Publisher version published on:

28 February 2021

\section{QUICK GLOSSARIUM}

Penulis menggunakan singkatan-singkatan berikut pada artikel ini.

\begin{tabular}{r|l}
$\mathbf{K D}$ & Kompetensi Dasar \\
\hline $\mathbf{P P K}$ & $\begin{array}{l}\text { Penguatan } \\
\text { Pendidikan } \\
\text { Karakter }\end{array}$ \\
\hline $\mathbf{4 C}$ & $\begin{array}{l}\text { Critical Thinking, } \\
\text { Creative Thinking, } \\
\text { Communication dan } \\
\text { Collaborative }\end{array}$ \\
\hline $\mathbf{5 M}$ & $\begin{array}{l}\text { Mengamati, } \\
\text { Menanya, } \\
\text { Mengumpulkan } \\
\text { Informasi, } \\
\text { Mengasosiasikan dan } \\
\text { Mengomunikasikan }\end{array}$
\end{tabular}

\begin{abstract}
The research objective was to describe the communication and collaboration skills of high school students in learning acid-base titration with guided inquiry and problem-based models. This type of research is library research with descriptive analysis. Secondary data used are literature in the form of books, journals and assessment rubrics. The data collection method is a documentation method with Miles \& Huberman data analysis. Based on the results of the literature review, it was found that students' communication and collaboration skills in learning acid-base titration with guided inquiry and problem-based models occurred at each stage. Acid-base titration learning activities using guided and problembased inquiry models train communication skills when discussing, asking, answering oral and written questions and collaborating when working together in class or in the laboratory.
\end{abstract}

\section{KEYWORDS}

Communication, Collaboration, Guided Inquiry, Problem-Based, Acid-Base Titration

\section{ABSTRAK}

Tujuan penelitian untuk mendeskripsikan keterampilan komunikasi dan kolaborasi siswa SMA pada pembelajaran titrasi asam-basa dengan model inkuiri terbimbing dan berbasis masalah. Jenis penelitian yaitu penelitian kepustakaan dengan analisis deskriptif. Data sekunder yang digunakan yaitu literatur berupa buku, jurnal dan rubrik penilaian. Metode pengumpulan data berupa metode dokumentasi dengan analisis data Miles \& Huberman. Berdasarkan hasil review literatur didapatkan hasil bahwa keterampilan komunikasi dan kolaborasi siswa pada pembelajaran titrasi asam-basa dengan model inkuiri terbimbing dan berbasis masalah terjadi pada setiap tahapan. Kegiatan pembelajaran titrasi asam-basa menggunakan model inkuiri terbimbing dan berbasis masalah melatih keterampilan komunikasi ketika berdiskusi, mengajukan, menjawab pertanyaan lisan maupun tulisan dan kolaborasi ketika bekerjasama di kelas ataupun di laboratorium.

\section{KATA KUNCI}

Komunikasi, Kolaborasi, Model Inkuiri Terbimbing, Berbasis Masalah, Titrasi Asam-Basa 


\section{PENDAHULUAN}

Kurikulum 2013 berorientasi pada penguatan pendidikan karakter $(\mathrm{PPK})^{[1]}$. Manfaat dan implikasi PPK bagi karakteristik siswa adalah mempersiapkan daya saing siswa dengan kompetensi abad ke-21 (4C) yaitu critical thinking, creative thinking, communication dan collaborative ${ }^{[2]}$. Komunikasi dan kolaborasi adalah dua dari empat keterampilan $4 \mathrm{C}$ yang harus dikuasai siswa di abad ke-21. Keterampilan komunikasi dan keterampilan kolaborasi saling berhubungan terutama dalam proses pembelajaran. Keterampilan komunikasi dapat membantu siswa mengomunikasikan hasil belajar sedangkan keterampilan kolaborasi merupakan kemampuan untuk bekerjasama dalam kelompok. Keterampilan komunikasi dan kolaborasi ini masih kurang kompeten di Indonesia terutama untuk pelajaran sains ${ }^{[3]}$ sehingga pemerintah meminta dalam meningkatkan keterampilan tersebut pembelajaran dilakukan dengan pendekatan saintifik 5M yakni: mengamati, menanya, mengumpulkan informasi, mengasosiasikan dan mengomunikasikan ${ }^{[4]}$. Model pembelajaran inkuiri terbimbing dan berbasis masalah merupakan dua dari empat pembelajaran yang menggunakan pendekatan saintifik.

Pembelajaran inkuiri terbimbing adalah pembelajaran menemukan konsep Model ini mempunyai 5 tahap yaitu: orientasi, eksplorasi, pembentukan konsep, aplikasi, penutup ${ }^{[5]}$. Pembelajaran berbasis masalah ialah pembelajaran memecahkan masalah. Tahapan model ini ada 5 yaitu: orientasi masalah, mengorganisasi, membimbing pengalaman individual/kelompok, mengembangkan dan menyajikan hasil karya, menganalisis dan mengevaluasi proses pemecahan masalah ${ }^{[6]}$. Pelaksanaan pembelajaran menggunakan dua model ini siswa bekerjasama dalam kelompok yang akan melibatkan keterampilan komunikasi dan kolaborasi.

Kimia adalah salah satu pelajaran sains yang menuntut keterampilan komunikasi dan kolaborasi dalam proses pembelajaran. Pelaksanaan pembelajaran kimia menggunakan model inkuiri terbimbing dan berbasis masalah siswa akan bekerjasama dengan kelompok saat diskusi di kelas dan saat bekerja di laboratorium serta mengomunikasikan hasil diskusi dan kerja kelompok secara lisan dan tulisan. Contohnya saat diskusi di kelas siswa memberikan hasil diskusi kepada guru dalam bentuk laporan sedangkan pada praktikum siswa diberikan tugas membuat laporan hasil percobaan, kedua kegiatan tersebut membutuhkan komunikasi tulisan. Laporan diskusi dan hasil percobaan yang diselesaikan memerlukan verifikasi dan evaluasi. Hasil laporan dipresentasikan di depan kelas dan membutuhkan kemampuan komunikasi lisan.

Titrasi asam-basa adalah materi pelajaran kimia kelas XI SMA yang menuntut siswa memiliki keterampilan komunikasi dan kolaborasi berdasarkan kompetensi dasar (KD) kurikulum 2013. KD titrasi asam-basa adalah 3.13 menganalisis data hasil berbagai jenis titrasi asam-basa dan 4.13 menyimpulkan hasil analisis data percobaan titrasi asam-basa. Apabila KD ini akan dilaksanakan dengan model inkuiri terbimbing dan berbasis masalah memungkinkan adanya pembelajaran berkelompok terutama pada KD 4.13 sedangkan KD 3.13 pembelajaran dapat dilakukan dengan kelompok atau tanpa kelompok, namun kedua $\mathrm{KD}$ tersebut siswa perlu mempresentasikan hasil diskusi dan hasil laporan yang membutuhkan komunikasi lisan dan tulisan. Pembelajaran titrasi asam-basa menggunakan dua model ini memungkinkan memunculkan komunikasi dan kolaborasi.

Tujuan penelitian untuk mendeskripsikan keterampilan komunikasi dan kolaborasi siswa pada pembelajaran titrasi asam-basa dengan model inkuiri terbimbing dan berbasis masalah. Rumusan masalah pada penelitian yaitu:

1. Bagaimana keterampilan komunikasi dan kolaborasi siswa pada pembelajaran titrasi asam-basa dengan model inkuiri terbimbing?

2. Bagaimana keterampilan komunikasi dan kolaborasi siswa pada pembelajaran titrasi asam-basa dengan model berbasis masalah?

\section{METODE}

Jenis penelitian adalah penelitian kepustakaan. Data yang diperoleh berasal dari koleksi perpustakaan tanpa memerlukan penelitian lapangan ${ }^{[7]}$. Jenis penelitian kepustakaan yang digunakan adalah tinjauan literatur semisistematis. Tinjauan semi-sistematis dilakukan untuk mengidentifikasi inti yang berkaitan dengan keterampilan komunikasi, keterampilan kolaborasi model inkuiri terbimbing, model berbasis masalah dan materi titrasi asam-basa. Sifat penelitian ini adalah analisis deskriptif yaitu menguraikan data yang didapatkan disertai dengan penjelasan agar dapat dipahami oleh pembaca.

Data sekunder adalah data yang digunakan pada penelitian ini, yaitu data yang sudah ada dan diperoleh peneliti dengan cara membaca, melihat atau mendengarkan. Sumber data diperoleh dari buku, jurnal dan rubrik penilaian.

Metode pengumpulan data adalah metode dokumentasi dengan mencari dan menggali data dari literatur yang berkaitan dengan rumusan masalah dalam penelitian. Data yang didapatkan berupa tulisan, gambar atau karya-karya monumental dari peneliti terdahulu yang dikumpulkan dan digunakan untuk menjawab permasalahan dalam penelitian ${ }^{[8]}$.

Situs www.elsevier.com, www.sciencedirect. com dan https://scholar.google.com/ ialah database yang digunakan untuk mencari artikel menggunakan istilah: model inkuiri terbimbing, tahap inkuiri terbimbing, proses pembelajaran inkuiri terbimbing, pembelajaran berbasis inkuiri, kegiatan pembelajaran berbasis inkuiri, model berbasis masalah, tahap berbasis masalah, pembelajaran 
berbasis masalah, proses pembelajaran berbasis masalah, keterampilan komunikasi, indikator komunikasi, komunikasi dalam pembelajaran, keterampilan kolaborasi, indikator kolaborasi, kolaborasi dalam pembelajaran, kegiatan titrasi asam-basa, tahap pembelajaran inkuiri terbimbing pada materi titrasi asam-basa, tahap pembelajaran berbasis masalah pada materi titrasi asam-basa.

Situs www.elsevier.com digunakan dalam proses pencarian artikel karena database ini memiliki 500.000 artikel setiap tahun di 2.500 jurnal, 17 juta dokumen dan 40.000 buku elektronik, www.sciencedirect.com digunakan karena mengandung lebih dari 12 juta konten dari 3.500 jurnal akademik dan 34.000 buku elektronik ${ }^{[9]}$ dan https://scholar.google.com/ digunakan karena menghasilkan satu juta jurnal baru setiap tahunnya ${ }^{[10]}$.

Pencarian artikel penelitian yang relevan dengan kriteria (1) kata-kata terkait penelitian dicari (2) pencarian dalam teks lengkap artikel (3) pencarian dalam teks lengkap artikel tersedia (4) diterbitkan sejak tahun 2010-2020.

Prosedur penelitian mengikuti langkahlangkah ${ }^{[1]}$ sebagai berikut: Pertama, merancang ulasan, dengan cara mencari dan menentukan literatur yang relevan dengan topik penelitian yaitu model pembelajaran inkuiri terbimbing, model pembelajaran berbasis masalah, kegiatan pembelajaran titrasi asam-basa, keterampilan komunikasi dan keterampilan kolaborasi. Kedua, melakukan tinjauan, dengan cara membaca literatur, melakukan tinjauan dengan membaca abstrak. Apabila abstrak sesuai dengan topik penelitian, kemudian artikel harus sesuai dengan kriteria inklusi (yang dapat mewakili subjek penelitian). Ketiga, analisis, menganalisis artikel untuk mendapatkan data informasi deskriptif seperti pengarang, tahun penerbit, topik, jenis penelitian dan hasil temuan. Keempat, menulis ulasan yang sesuai dengan topik penelitian. Ulasan yang ditulis mengenai kegiatan tahap inkuiri terbimbing; aturan dalam mengevaluasi; kegiatan tahap berbasis masalah; aturan dalam pembelajaran berbasis masalah; indikator dan kegiatan keterampilan komunikasi lisan, komunikasi tulisan serta kolaborasi; hambatan pada kolaborasi; kegiatan titrasi asam-basa pada tahap inkuiri terbimbing dan berbasis masalah; kegiatan titrasi asam-basa secara nasional.

\section{HASIL DAN DISKUSI}

Hasil analisis literatur didapatkan dengan menggabungkan hasil studi dari 17 literatur, dengan rincian sebagai berikut: 1) tahap pembelajaran inkuiri terbimbing ${ }^{[5,12-13]}$; 2) hasil penelitian inkuiri ${ }^{[14]}$; 3) tahap pembelajaran berbasis masalah ${ }^{[, 15-16]}$; 4) hasil penelitian berbasis masalah ${ }^{[17]}$; 5) indikator keterampilan komunikasi $\operatorname{lisan}^{[18]}$; 6) indikator keterampilan komunikasi tulisan ${ }^{[19]}$; 7) hasil penelitian keterampilan komunikasi ${ }^{[20-21]} ; 8$ ) indikator keterampilan kolaborasi ${ }^{[22]}$; 9) hasil penelitian keterampilan kolaborasi ${ }^{[23]}$; 10) kegiatan titrasi asam-basa tahap inkuiri ${ }^{[24]}$;11) kegiatan titrasi asam-basa tahap berbasis masalah ${ }^{[25]}$ 12) silabus

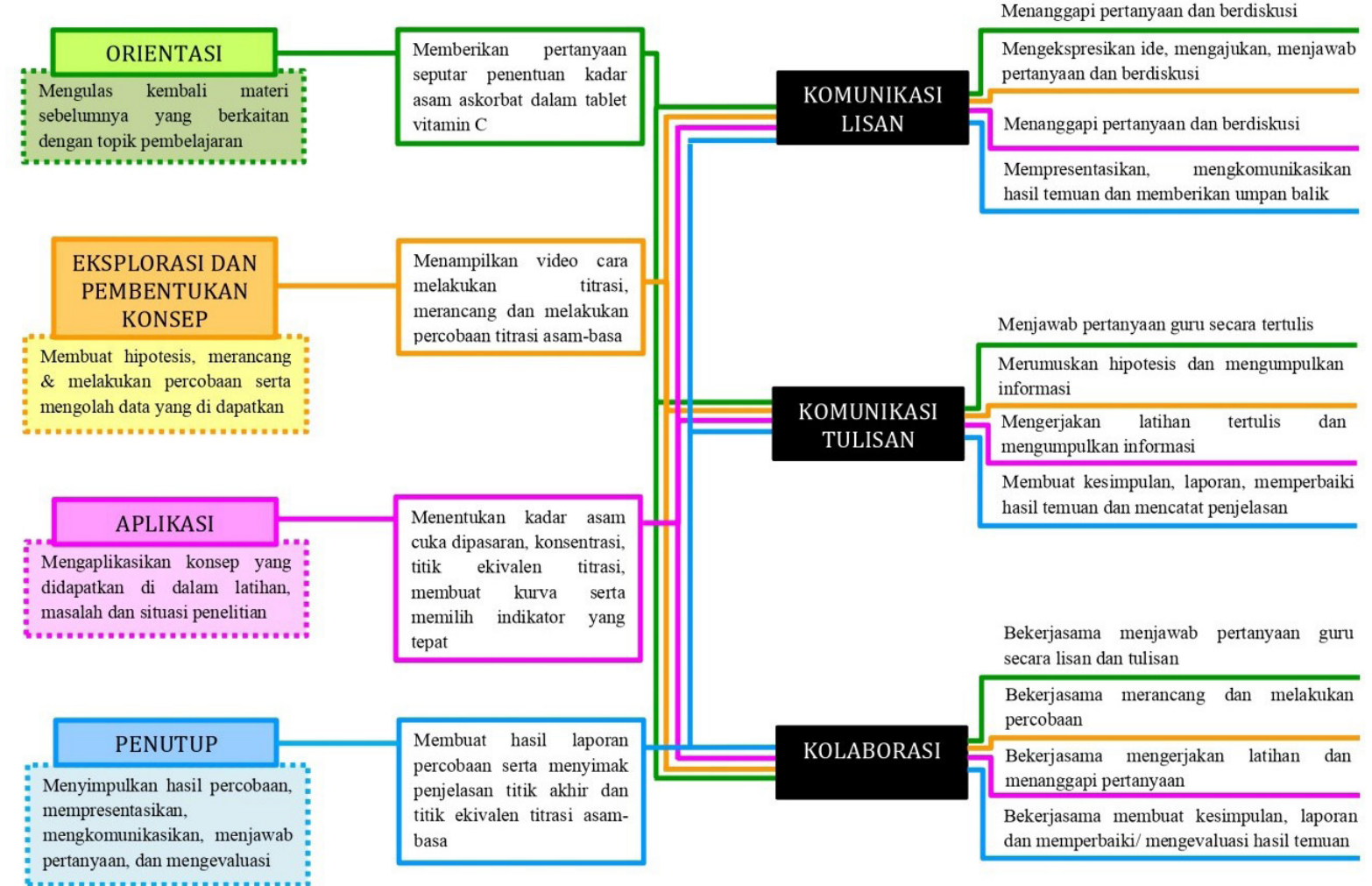

Gambar 1. Keterampilan komunikasi dan kolaborasi siswa pada pembelajaran titrasi asam-basa dengan model inkuiri terbimbing. 
nasional kegiatan titrasi asam-basa ${ }^{[26]}$. Analisis dari berbagai literatur tersebut menghasilkan sebuah kesimpulan yang terdapat pada Gambar 1 dan Gambar 2.

Gambar 1 terdiri dari tiga bagian yaitu tahap model inkuiri terbimbing (hasil analisis ${ }^{[5,12-13]}$; kegiatan titrasi asam-basa (hasil analisis ${ }^{[24,26]}$ ); kegiatan terjadinya komunikasi dan kolaborasi (hasil analisis ${ }^{[18-23]}$ ). Gambar 2 terdiri dari tiga bagian yaitu tahap model berbasis masalah (hasil analisis ${ }^{[6,15-16]}$; kegiatan titrasi asambasa (hasil analisis ${ }^{[25-26]}$ ); kegiatan terjadinya komunikasi dan kolaborasi (hasil analisis ${ }^{[18-23]}$ ).

\subsection{Keterampilan komunikasi dan kolaborasi siswa pada pembelajaran titrasi asam-basa menggunakan model inkuiri terbimbing.}

\subsubsection{Orientasi}

Kegiatan orientasi pada pembelajaran titrasi asam-basa bertujuan mengulas kembali materi sebelumnya yang berhubungan dengan titrasi asam-basa. Seperti memberikan pertanyaan seputar pengertian konsentrasi, cara menghitung konsentrasi, contoh asam kuat, asam lemah, basa kuat dan basa lemah, cara menghitung $\mathrm{pH}$ asam dan basa. Proses ini melibatkan komunikasi lisan, tulisan dan kolaborasi.

Komunikasi lisan terjadi ketika siswa menanggapi pertanyaan guru secara lisan dan berdiskusi dengan teman untuk menjawab pertanyaan guru. Komunikasi tulisan terjadi ketika siswa menjawab pertanyaan guru dalam bentuk soal di buku catatan/latihan atau dijawab langsung di papan tulis. Kolaborasi terjadi ketika siswa bekerjasama menjawab pertanyaan guru secara lisan maupun tulisan.

\subsubsection{Eksplorasi dan pembentukan konsep}

Kegiatan eksplorasi dan pembentukan konsep pada pembelajaran titrasi asam-basa bertujuan untuk membuat hipotesis dari video titrasi yang dipandu dengan pertanyaan guru seperti "asam askorbat termasuk ke dalam jenis asam apa? bagaimana cara menentukan kadar asam askorbat?; larutan apa yang perlu ditambahkan?; larutan di buret disebut titran, apa itu titran?; larutan di erlenmeyer disebut titrat, apa itu titrat?". Siswa juga dapat mengamati perbandingan video titrasi menggunakan indikator dan tanpa indikator, dari kedua video dapat diberikan pertanyaan seperti "larutan yang ditambahkan ke dalam erlenmeyer disebut indikator, apa itu indikator? Bagaimana jika saat melakukan titrasi tidak ditambahkan indikator?".

Teknologi skrip dapat membantu guru dan siswa memilih hipotesis dan metodologi mereka sendiri dengan bebas. Memberikan kebebasan kepada siswa bukan berarti membiarkan siswa belajar tanpa adanya informasi. Memberikan informasi terlalu banyak juga akan mengurangi kebebasan siswa untuk kolaborasi secara produktif. Di sinilah pentingnya kemampuan guru dalam membuat skrip yang dapat mendukung siswa untuk berkomunikasi dan berkolaborasi ${ }^{[13]}$. Informasi yang diberikan membantu siswa dalam merancang dan melakukan percobaan serta mengolah data.

Ketika siswa melakukan percobaan, sebaiknya setiap kelompok diberikan masalah yang berbeda seperti membedakan titrat dan titran, sehingga masing-masing kelompok menemukan konsep mereka sendiri tanpa ada unsur meniru atau mengambil data dari kelompok lain. Proses ini melibatkan komunikasi lisan, tulisan dan kolaborasi.

Komunikasi lisan terjadi ketika siswa mengekspresikan ide, mengajukan, menjawab pertanyaan dan berdiskusi dengan teman saat melakukan percobaan. Komunikasi tulisan terjadi ketika siswa mengumpulkan informasi mengenai titrasi asam-basa, merumuskan dan menjawab hipotesis pertanyaan, menganalisis data dan merangkumnya dalam tabel. Kolaborasi terjadi ketika siswa memilih peralatan metode dan tindakan yang harus dilakukan, melakukan dan merancang percobaan, berdiskusi dalam menganalisis data/informasi.

\subsubsection{Aplikasi}

Kegiatan titrasi asam-basa pada tahap aplikasi bertujuan untuk mengaplikasikan konsep yang didapatkan dengan memberikan latihan berupa soal ataupun menginstruksikan siswa melakukan percobaan yaitu menentukan kadar asam cuka di pasaran, menentukan konsentrasi pentiter/zat yang dititrasi, menentukan titik ekivalen titrasi asam-basa, membuat kurva serta memilih indikator yang tepat. Apabila guru menginstruksikan siswa melakukan percobaan sebaiknya setiap kelompok melakukan percobaan yang sama. Tujuannya apabila terdapat perbedaan pada hasil percobaan masing-masing kelompok dapat dibahas pada tahap selanjutnya. Proses ini melibatkan komunikasi lisan, tulisan dan kolaborasi.

Keterampilan komunikasi lisan terjadi ketika siswa menanggapi pertanyaan dan berdiskusi. Komunikasi tulisan terjadi ketika mengerjakan latihan tertulis dan mengumpulkan informasi. Kolaborasi terjadi ketika siswa bekerjasama mengerjakan latihan dan menanggapi pertanyaan guru.

\subsubsection{Penutup}

Kegiatan titrasi asam-basa pada tahap penutup bertujuan menyimpulkan hasil percobaan, mempresentasikan, mengomunikasikan, menjawab pertanyaan dan mengevaluasi. Apabila di tahap aplikasi, siswa menemukan perbedaan data ataupun kurva titrasi maka guru dapat mendiskusikan dengan siswa penyebab terjadinya perbedaan. Guru dapat bertanya bagaimana cara siswa melakukan titrasi, indikator yang digunakan setelah itu guru dapat memberikan penjelasan dan cara melakukan titrasi yang benar. Proses ini melibatkan komunikasi lisan, tulisan dan kolaborasi.

Komunikasi lisan terjadi ketika siswa mempresentasikan, mengomunikasikan hasil temuan, memberikan umpan balik dan merefleksikan keberhasilan metode. Komunikasi tulisan terjadi 


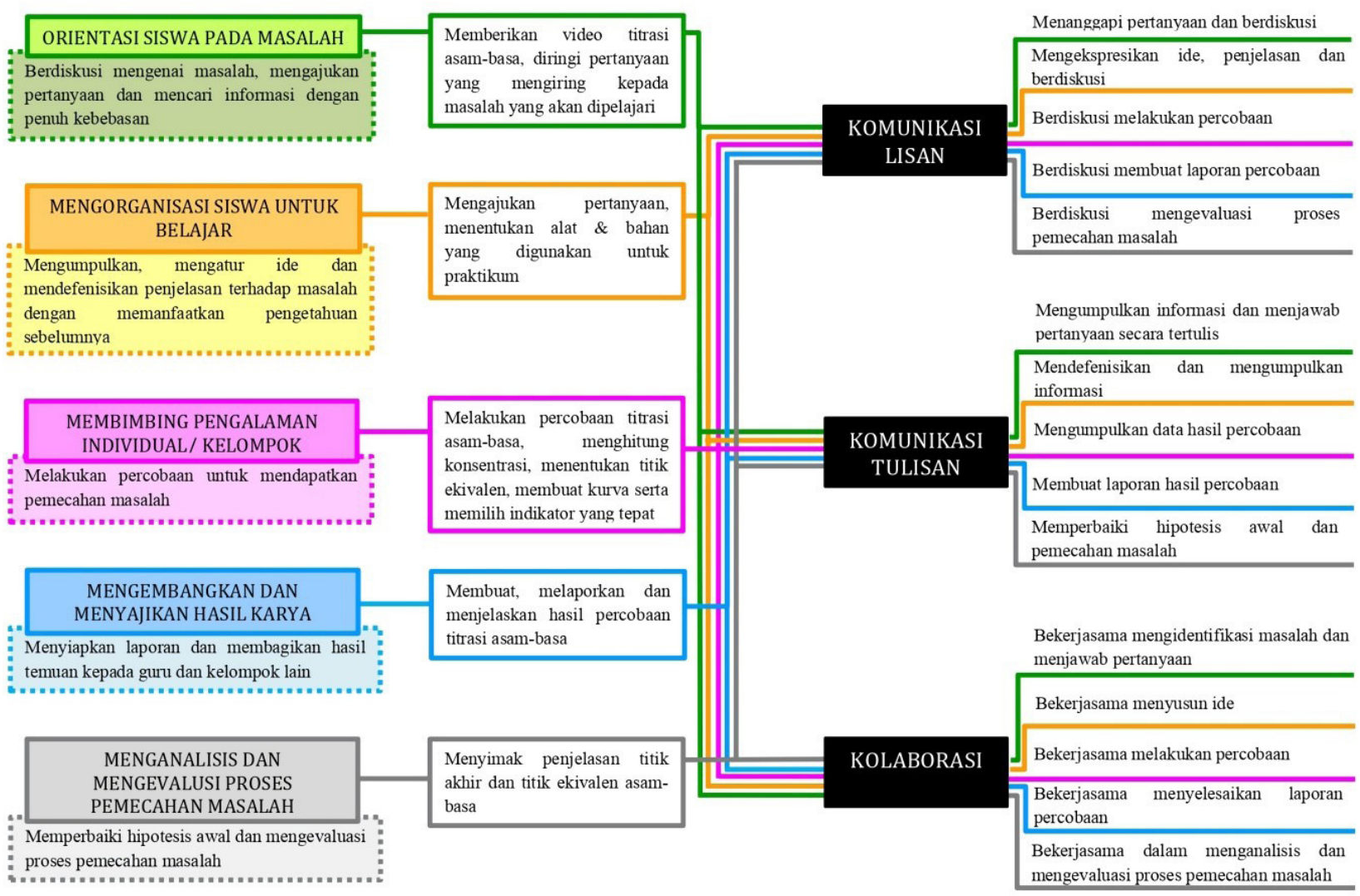

Gambar 2. Keterampilan komunikasi dan kolaborasi siswa pada pembelajaran titrasi asam-basa dengan model berbasis masalah.

ketika siswa membuat kesimpulan; laporan; memperbaiki hasil temuan dan mencatat penjelasan yang disampaikan guru. Kolaborasi terjadi ketika siswa bekerjasama membuat kesimpulan, laporan dan memperbaiki/mengevaluasi hasil temuan.

\subsection{Keterampilan komunikasi dan kolaborasi siswa pada pembelajaran titrasi asam-basa menggunakan model berbasis masalah}

\subsubsection{Orientasi siswa pada masalah}

Kegiatan titrasi asam-basa pada tahap orientasi siswa pada masalah bertujuan untuk mendiskusikanmengenaimasalahyangditampilkan dalam video titrasi asam-basa diiringi pertanyaanpertanyaan yang mengiring kepada masalah yang akan dipelajari, siswa mengumpulkan informasi berupa data/fakta yang relevan dari berbagai literatur. Proses ini melibatkan komunikasi lisan, tulisan dan kolaborasi.

Komunikasi lisan terjadi ketika siswa menanggapi pertanyaan, menyatakan ide-ide secara terbuka dan berdiskusi. Komunikasi tulisan terjadi ketika siswa mengumpulkan informasi atau konsep yang tidak mereka pahami maupun menjawab pertanyaan secara tertulis. Kolaborasi terjadi ketika siswa bekerjasama mengidentifikasi masalah dan menjawab pertanyaan guru dalam bentuk lisan dan tulisan.

\subsubsection{Mengorganisasi siswa untuk belajar}

Kegiatan titrasi asam-basa pada tahap mengorganisasi siswa untuk belajar bertujuan mengumpulkan informasi alat dan bahan yang digunakan, mengatur ide, dan mendefinisikan penjelasan terhadap masalah dengan memanfaatkan pengetahuan sebelumnya. Proses ini melibatkan komunikasi lisan, tulisan dan kolaborasi.

Komunikasi lisan terjadi ketika siswa mengekspresikan ide, penjelasan dan berdiskusi. Komunikasi tulisan terjadi ketika siswa mendefinisikan dan mengumpulkan informasi penyelidikan yang akan dilakukan. Kolaborasi terjadi ketika siswa bekerjasama menyusun ide.

\subsubsection{Membimbing pengalaman individual/kelompok}

Kegiatan titrasi asam-basa pada tahap membimbing pengalaman individual/kelompok bertujuan melakukan percobaan, menghitung dan menentukan titik ekivalen titrasi, membuat kurva titrasi serta memilih indikator yang tepat, menentukan konsentrasi pentiter/zat yang dititrasi dan melaporkan hasil percobaan titrasi asam-basa. Proses ini melibatkan komunikasi lisan, tulisan dan kolaborasi.

Komunikasi lisan terjadi ketika siswa berdiskusi selama percobaan. Komunikasi tulisan terjadi saat siswa mengumpulkan informasi/data dari percobaan. Kolaborasi terjadi ketika siswa bekerjasama dalam percobaan.

\subsubsection{Mengembangkan dan menyajikan hasil karya \\ Kegiatan titrasi asam-basa pada tahap} mengembangkan dan menyajikan hasil karya 
bertujuan membuat laporan percobaan, melaporkan dan menjelaskan hasil percobaan titrasi asambasa yang telah dilakukan. Proses ini melibatkan komunikasi lisan, tulisan dan kolaborasi.

Komunikasi lisan terjadi saat siswa berdiskusi dalam menyelesaikan laporan praktikum. Komunikasi tulisan saat siswa membuat laporan hasil percobaan. Kolaborasi terjadi ketika siswa bekerjasama menyelesaikan laporan percobaan.

\subsubsection{Menganalisis dan mengevaluasi proses pemecahan masalah}

Kegiatan titrasi asam-basa pada tahap menganalisis dan mengevaluasi proses pemecahan masalah bertujuan membantu siswa untuk melakukan refleksi atau evaluasi terhadap proses pemecahan masalah/memperbaiki hipotesis awal dan menyimak penjelasan guru. Proses ini melibatkan komunikasi lisan, tulisan dan kolaborasi.

Komunikasi lisan terjadi ketika siswa berdiskusi mengevaluasi proses pemecahan masalah. Komunikasi tulisan terjadi ketika siswa memperbaiki hipotesis awal mereka berdasarkan apa yang telah mereka pelajari. Kolaborasi terjadi ketika siswa bekerjasama dalam menganalisis, mengevaluasi dan merefleksikan proses pemecahan masalah dan aktivitas pembelajaran yang telah dilakukan.

Kendala umum yang terjadi selama siswa berkolaborasi yaitu (1) kurangnya keterampilan kolaboratif, sebagian besar siswa tidak tahu bagaimana menggunakan keterampilan kolaboratif secara efektif; (2) penumpang gratis, ketika berkolaborasi dalam tugas-tugas kelompok, beberapa siswa berkontribusi paling besar, sementara yang lain bekerja lebih sedikit dan beberapa bahkan tidak berupaya ketika menyelesaikan tugas mereka sendiri; (3) status kompetensi, siswa pintar dalam kelompok belajar umumnya diyakini aktif dan kompeten. Siswa yang pintar sebagian besar idenya diterima oleh mayoritas anggota kelompok mereka dengan sukarela. Sehingga siswa yang pintar cenderung meremehkan kapasitas intelektual anggota yang di bawah mereka; (4) ikatan persahabatan, hubungan pertemanan dalam kelompok merupakan hambatan bagi kolaborasi yang efektif. Ikatan persahabatan dalam kelompok kadang-kadang menghambat mereka untuk bekerja dengan serius dan membangun argumen yang baik ${ }^{[23]}$.

Tahap penutup pada model inkuiri terbimbing dan tahap mengevaluasi proses pemecahan masalah pada model berbasis masalah, memiliki kesamaan kegiatan yaitu mengevaluasi. Agar kegiatan evaluasi ini sesuai dengan fungsinya maka guru perlu mengetahui aturan dalam mengevaluasi. Terdapat empat aturan dalam mengevaluasi yakni sebagai berikut.

Pertama, fokus pada evaluasi proses pembelajaran, bukan pada hasilnya. Dalam proses pemecahan masalah, apabila siswa mengetahui apa kekurangan dan hal yang mereka butuhkan. Pada saat yang sama, mereka telah mengonsolidasikan pengetahuan yang mereka pelajari dan mengalami lebih banyak dari pengetahuan mereka sendiri dengan pengalaman langsung.

Kedua, temuan evaluasi harus ditargetkan, bukan peringkat sederhana. Dalam evaluasi pembelajaran siswa, guru harus menunjukkan di mana kelebihan dan kekurangan dari tugas siswa. Guru harus memberi penjelasan yang rinci, agar siswa memahami masalah mereka sendiri dan dapat menyelesaikannya pada situasi yang sama. Guru harus memberi tahu bila siswa melakukan kesalahan di waktu yang tepat. Ketika siswa menyadari kekurangan mereka sendiri dalam menangani beberapa jenis masalah, mereka dapat menghindari beberapa masalah seperti itu di masa depan. Guru ditekankan untuk tidak menghentikan siswa jika mereka menemukan siswa melakukan metode yang salah kecuali metode tersebut akan merusak peralatan. Mereka juga diminta untuk tidak menjelaskan metode spesifik kecuali jika siswa meminta mereka melakukannya tetapi siswa perlu memilih metode sebelumnya ${ }^{[17]}$.

Ketiga, guru harus fokus pada aplikasi dari pada memori mekanik. Evaluasi tidak hanya memperhatikan penguasaan siswa dalam pengetahuan dan temuan penelitian saja, tetapi juga mengenai fleksibilitas pengetahuan dan keterampilan siswa.

Keempat, menggunakan evaluasi keanekaragaman, dengan fokus pada evaluasi diri siswa dan evaluasi teman sebaya. Evaluasi pembelajaran harus diselesaikan secara sepihak oleh guru, penilaian diri sendiri, penilaian teman sebaya serta evaluasi orang tua dan ahli lainnya ${ }^{[14]}$.

\section{SIMPULAN}

Berdasarkan hasil penelitian kepustakaan yang dilakukan, disimpulkan (1) Keterampilan komunikasi dan kolaborasi siswa pada pembelajaran titrasi asam-basa dengan model inkuiri terbimbing dapat dilihat pada setiap tahapannya yaitu orientasi, eksplorasi dan pembentukan konsep; aplikasi dan penutup (2) Keterampilan komunikasi dan kolaborasi siswa pada pembelajaran titrasi asam-basa dengan model berbasis masalah dapat dilihat pada setiap tahapannya yaitu orientasi siswa pada masalah; mengorganisasi siswa untuk belajar; membimbing pengalaman individual/kelompok; mengembangkan dan menyajikan hasil karya; menganalisis dan mengevaluasi proses pemecahan masalah (3) Kegiatan pembelajaran titrasi asambasa menggunakan model inkuiri terbimbing dan berbasis masalah dapat melatih keterampilan komunikasi dan kolaborasi siswa (4) Kegiatan titrasi asam-basa melibatkan keterampilan komunikasi lisan ketika siswa berdiskusi melakukan praktikum, mengajukan dan menjawab pertanyaan secara lisan; komunikasi tulisan ketika siswa membuat laporan praktikum, merumuskan dan menjawab pertanyaan secara tertulis; kolaborasi ketika siswa bekerjasama dalam mengerjakan latihan, melakukan praktikum, menyelesaikan laporan praktikum dan berdiskusi menjawab pertanyaan. 


\section{REFERENSI}

1. Presiden Republik Indonesia. Penguatan Pendidikan Karakter. Indonesia; 2017.

2. Harjanti MH. The Implementation of the 21Th Century Competency for Elementary School Teachers At Curriculum 2013 Training Central Java Province Year 2017. Soc Humanit Educ Stud Conf Ser. 2018;1(1):523-31.

3. Zubaidah S. Keterampilan Abad Ke-21: Keterampilan yang Diajarkan Melalui Pembelajaran. J Penelit Pendidik. 2016;(2):1-15.

4. Indonesia PMP dan KR. Standar Proses Pendidikan Dasar dan Menengah. Indonesia; 2013.

5. Hanson DM. Designing Process-Oriented Guided-Inquiry Activities. 2005;281-4.

6. Arends RI. Learning to Teach. Ninth Edit. New York: Mc Graw Hill; 2012. 1-573 p.

7. Zed M. Metode Penelitian Kepustakaan. Jakarta: Yayasan Obor Indonesia; 2004. 1-3 p.

8. Sugiyono. Metode Penelitian Pendidikan Kombinasi (Mixed Methods). Bandung: Alfabeta; 2011.

9. RELX. 2018 RELX Group Annual Report. 2018.

10. Rafika AS, Putri HY, Widiarti FD. Analisis Mesin Pencarian Google Scholar Sebagai Sumber Baru Untuk Kutipan. 2017;3(2):193-205.

11. Snyder H. Literature Review as a Research Methodology : An Overview and Guidelines. J Bus Res. 2019;104(July):333-9.

12. Pedaste, M., Mäeots, M., Siiman, L. A., De Jong, T., Van Riesen, S. A., Kamp, E. T., ... \& Tsourlidaki, E. (2015). Phases of inquiry-based learning: Definitions and the inquiry cycle. Educational research review, 14, 47-61.

13. Scanlon E, Anastopoulou S, Kerawalla L, Mulholland P. How Technology Resources Can Be Used to Represent Personal Inquiry And Support Students' Understanding of It Across Contexts. J Comput Assist Learn. 2011;27:516-29.

14. Xue-song L, Qi-hui L, Jie C. Inquiry Learning’ Implementation and Evaluation in the Teaching of Information Technology. Phys Procedia. 2012;24:1851-6.

15. Hmelo-Silver CE. Problem-Based Learning: What and How Do Students Learn? Educ Psychol Rev. 2004;16(3):235-66.

16. Wood DF. ABC of Learning and Teaching in Medicine Problem Based Learning. Clin Rev. 2003;326:328-30.

17. Baharom S, Hamid R, Hamzah N. Development of a Problem Based Learning in Concrete Technology Laboratory Work. Procedia - Soc Behav Sci [Internet]. 2012;60:8-13. Available from: http://dx.doi.org/10.1016/j. sbspro.2012.09.339

18. Program GC. Oral Communication Rubric.

19. Rubric for Written Communication Skills.

20. Kofli NT, Rahman NA. The Open Ended Laboratory for Measurement of Communication Skill for Chemical /
Biochemical Engineering Students. Procedia Soc Behav Sci. 2011;18:65-70.

21. Iksan ZH, Zakaria E, Meerah TSM, Osman K, Lian DKC, Mahmud SND, et al. Communication Skills among University Students. Procedia - Soc Behav Sci. 2012;59:71-6.

22. Valente L. CO-LAB Guidelines for Assessing Collaborative Learning in the Classroom. European Schoolnet; 2016. 1-20 p.

23. Le H, Janssen J, Wubbels T. Collaborative Learning Practices: Teacher and Student Perceived Obstacles to Effective Student Collaboration. Cambridge J Educ. 2018;48(1):103-22.

24. Amalia NR, Rosanti W, Susatyo EB, Harjito. Analisis Keterampilan Dasar Laboratorium dengan Pembelajaran Pogil pada Materi Titrasi Asam Basa. Chem Educ. 2019;8(1):1-7.

25. Al-Faruq H. Keterampilan Proses Sains Siswa Kelas XI Pada Pembelajaran Titrasi Asam Basa Menggunakan Metode Problem Solving. Universitas Islam Negeri Syarif Hidayatullah; 2015.

26. Kementerian Pendidikan dan Kebudayaan. Silabus SMA K13 Revisi 2018. 